\title{
Maritime Terrorism and Piracy: The Threat to Maritime Security
}

\author{
Natalya A. Knyazeva ${ }^{1}$ \\ Alexander I. Korobeev² \\ ${ }^{1}$ Far Eastern Federal University, Vladivostok, Russia \\ ¿Law School, Far Eastern Federal University, Vladivostok, Russia
}

Doi:10.5901/mjss.2015.v6n6s3p226

\section{Abstract}

This article analyzes the current dynamics and tendencies of piracy and maritime terrorism. The authors highlight certain categories of piracy and maritime terrorism attacks depending on the methods and purposes of their execution. They consider the statistics of committed pirate attacks and outline the main regions where acts of piracy and maritime terrorism take place. They also carried out an analysis of the major provisions of the conventions and other acts regulating the issues involved in combating piracy and maritime terrorism. Attention is drawn to the fact that piracy and maritime terrorism have certain similarities. The authors highlight distinctive features of piracy and maritime terrorism; they also emphasize the need to consider these two crimes separately in order to counteract such negative criminal phenomena more effectively.

Keywords: piracy, maritime terrorism, maritime security, counteract, crime.

\section{Introduction}

In today's world maritime terrorism and piracy constitute a serious threat to the safety of navigation and the life and wellbeing of seafarers and passengers of ships. It can also lead to heavy losses in international trade and cause significant economic damage to many countries (Knyazeva \& Knyazeva, 2014).

Maritime terrorism has evolved from piracy. In the modern sense piracy is a crime of an international character consisting of unlawful seizure, plundering, or the sinking of commercial or civil ships on the high seas.

According to the International Maritime Bureau (IMB) in 2012 they made 297 attacks on ships, in 2013 there were 264 cases and in 2014245 ships were attacked (Report of the International Maritime Bureau, 2015).

At the same time the number of reported cases of piracy and armed robbery against ships around the world in 2013 was the lowest in six years. The main reason for the reduction in the total number of incidents of piracy in the world has been a decrease in the number of attacks by Somali pirates off the coast of East Africa. According to the IMB, actions of piracy were constrained by a set of factors, among which were an increase in anti-piracy features on vessels, the use of private, armed security groups and the stabilizing effect of the central government of Somalia. International naval forces also played a key role. However, the frequent attacks on small tankers off the coast of South-East Asia led to an increase in the number of seizures of vessels despite worldwide pirate activity declining to its lowest level in eight years. frequent.

Thus, the geography of pirate attacks is gradually changing - now attacks by pirates in Southeast Asia are the most

Contemporary piracy is the activity of criminal organizations and is becoming more extensive and more violent. This includes attacks on merchant, fishing, auxiliary and other ships for the purpose of robbing the crew, seizing goods and abducting ships with cargo for their subsequent sale, and crew members - for ransom (Eshchenko \& Novikov, 2014). In addition, the geography of pirate attacks is quite extensive and includes the waters of the Caribbean, West Africa, the Straits of Malacca, the South China Sea and the coastal area of Hindustan. Therefore, the problem of piracy as a constituent part of maritime crime is global in geographical terms.

Also, reports about the relationship between pirates and terrorists, in particular the radical Islamist group "Al Shabab" whose ambitions for power in Somalia are disturbing. In fact, the connection between terrorism and organized crime (such as drug dealing) is generally known. Nevertheless, piracy, as a source of replenishment for Islamic terrorists in the area of the Horn of Africa, can result in the creation of groups that are terrorist oriented and which export terrorism around the world.

Maritime terrorism and piracy are a form of international terrorism. In this context, international terrorism became one of the main concerns with its highly complicated characteristics. This problem has been recognized not only by one 
nation, but also in the era of globalization when the nations became much more connected and interdependent, it became a threat to international security (Pidzhakov, Mayor, Balyasnikov, Bayramov \& Zeleneva, 2015).

Various measures for the prevention of piracy and maritime terrorism are taken both by the countries concerned and within the international organizations including the United Nations, the International Maritime Organization (IMO), the EU, NATO, and the League of Arab States. The UN Security Council is also addressing this problem which is a strong indication of its severity. From 2008 to 2014 the UN Security Council adopted several resolutions concerning the problem of piracy and maritime terrorism in Somalia. This area is currently being patrolled by approximately 35 warships from 16 countries. This is the most powerful anti-piracy flotilla presently active. However, the problem of suppressing piracy and maritime terrorism still remains unresolved which indicates a lack of existing measures to combat it.

Many legal scholars have been engaged in studying the problems of piracy and maritime terrorism and measures to combat them, in particular, A.I. Korobeev, L.A. Modzhoryan, T.I. Nagayeva, V.V. Rovneiko, Y.C. Romashev, V.F. Sidorchenko and others. Nevertheless, they do not address the problem of piracy and maritime terrorism in the context of independent research. In addition, many of the existing studies are outdated and do not meet the modern realities of combating such threats. Studies relate, as a rule, to the investigation of criminal matters in order to combat acts against the safety of maritime navigation. However, acts of piracy and maritime terrorism require more detailed study in order to identify their individual type and inherent characteristics as well as the distinctive features of these illegal phenomena.

The goal of this study is to examine the main characteristics of threats to maritime security such as piracy and maritime terrorism.

The paper presents the most common types of pirate and terrorist attacks and draws a parallel between piracy and maritime terrorism. This analysis will help to develop more effective methods to combat these crimes.

\section{Methods}

The methodological basis of the study is the dialectical method of cognition of phenomena and processes of objective reality. General scientific (empirical sociological, induction, deduction, system-structural, expert evaluation) and special (logical, comparative-legal, etc.) methods were used for the collection, processing, compilation, analysis and interpretation of the material.

In the preparation of this article provisions of the general theory of law, criminal law theory, and scientific works of Russian scientists in the field of criminal and international law specifically devoted to the studied topics were used.

\section{Results and Discussion}

This section looks at the various definitions of pirate attacks and acts of maritime terrorism, the differences between piracy and maritime terrorism and the risk categories of terrorist attacks in relation to maritime transport.

\subsection{Types of pirate attacks and maritime terrorism}

The study identified the main types of pirate attacks and acts of maritime terrorism.

First, in order to establish features common to these criminal phenomena and make a broad distinction between them we will identify the particular characteristics of piracy.

International crime in the form of maritime piracy has a very ancient history. It originated concurrently with the development of maritime trade and the beginnings of warfare at sea. Piracy has affected commercial shipping for almost as long as the world's oceans and seas have been used for trade.

Prior to the adoption of the Geneva Convention on the High Seas in 1958 piracy as a phenomenon of international law was defined in different ways. Many foreign lawyers believed that the following elements were needed to qualify an act as maritime piracy: a) an act committed by force of arms; b) connection of the offence with the sea; c) the existence of a danger for all (Korobeev, 2015). In other words, use of the term piracy implied any act of violence against people and goods which a private vessel committed against another vessel on the sea without proper authorization.

The legal definition of piracy was first given at the Convention on the High Seas in 1958 and was then presented at the UN Convention on the Law of the Sea of 1982. According to Art. 15 of the Convention of 1958 and Art. 101 of the Convention of 1982 the following actions are recognized as piracy:

a) any illegal act of violence, detention, or robbery, committed for personal ends by the crew or passengers of a private ship or a private aircraft, and directed against:

any other vessel or aircraft on the high seas or against persons or property on board; 
any ship or any aircraft, persons or property in a place outside the jurisdiction of any state;

b) any act of voluntary participation in the use of a ship or an aircraft if the person who commits this act is aware of the circumstances which render this vessel or aircraft a pirate ship or a pirate aircraft;

c) any action which incites or intentionally facilitates an act specified in paragraphs "a" or "b" (the Geneva Convention on the High Seas, 1958; United Nations Convention on the Law of the Sea, 1982).

Based on these Conventions any similar actions committed by a military or a government ship or a government aircraft whose crew has mutinied and taken control of that vessel or aircraft are equivalent to piracy. Because maritime piracy and other criminal acts committed on the high seas are closely related the international community has adopted a number of regulations that govern the fight against them. In particular, the Convention of 1988 on the suppression of unlawful acts directed against the safety of maritime navigation and the Protocol of 1988 on the suppression of unlawful acts against the safety of fixed platforms located on the continental shelf.

The International Maritime Organization which has been intensively engaged in the problems of piracy divides piracy into three categories:

1. Low Level Armed Robbery (LLAR) - small gangs acting on their own and who prefer a rapid raid after which the pirates rapidly disappear with the easy loot - money or valuables. The crew often discovers the loss only after the disappearance of the raiders. They occasionally make use of light thrust and hacking weapons and firearms which can be a danger to not only ship crews; for example, the discharging of firearms on board a tanker can have serious consequences. These attacks are carried out against ships at anchor or vessels nearing port when the gangs can rapidly board from the sea, freely pillage the ship and quickly escape. This category of pirates is not interested in serious confrontation during the course of their actions. There have been instances when such pirates, having encountered a crew's organized resistance, retreated emptyhanded.

2. Medium Level Armed Assault and Robbery (MLAAR). This type of attack is carried out by organized criminal groups having associations with ports' staff. They regularly stalk potential victims in their harbors and execute raids with automatic weapons and sometimes anti-tank grenade launchers in the coastal waters in speedboats.

Pirates who are well-armed with automatic and other weapons and equipped with speedboats are able to seize a ship and retain possession of it long enough to steal various kinds of property and freely leave. Ships that have been so attacked are sometimes left without a watch officer or a navigator and this increases the risk of an accident when being so close to shore.

When carrying out their armed attacks pirates initially used primitive means to stop a ship. Gradually, however, pirate groups became equipped with modern speedboats allowing them to intercept and seize ships on the high seas. The analysis of such pirate attacks shows that some groups of pirates have received special military training.

2. Major Criminal Hijack (MCHJ). This attack requires significant investment in the preparation and execution of the attack. International organized groups are engaged in this type of piracy and capture ships with high-value goods. They use modern systems of satellite navigation and communications; have a network of agents and extensive contacts throughout various levels of government. From the point of view of the target of the attack, this type of piracy can be subdivided into two categories. The first category includes an armed attack on a ship to capture cargo with an ensuing transfer of goods to another vessel at sea.

The distinctive feature of the second category of piracy is the seizure of trade and transport ships, especially tankers, followed by the compiling of bogus documents pertaining to the captured vessels or bogus temporary registration of ships under another country's "flag of convenience". Ships are given new names, equipped with new crews and then fraudulently leased to ship owners and transport companies. Through this process vessels disappear altogether with their cargos. International criminal groups engage in this category of piratical seizure.

According to M. Kurshev's informed opinion, only they "are able to steal entire ships with cargo, rename or re-paint them, falsify vessel papers (data on cargo and crew), and sometimes sell the ships. Such operations are impossible without corrupt port authority staff and police. This sophisticated version of piracy is also known as "ghost ships"(Kurshev, 2006).

This type of pirate attack is dangerous for both the ship owners and the ship crews. Over the course of such an action the ship's crew may be taken aboard a pirate ship or left to their fate. Nevertheless, the pirates simply kill the crew in order to leave no witnesses to the crime.

Analysts point out that this type of piracy wherein vessels are hijacked prevailed in the mid and late 90s of the XX century in the waters of Southeast Asia, especially in the South China Sea. There pirates were able to successfully 
conduct their operations because they could use the Chinese ports as shelters. Pirates freely accessed the Chinese ports exploiting the imperfect legislation and the weak law enforcement authorities of the PRC. Apart from those already specified in the report of IMO forms of piracy, we can distinguish several varieties of pirate attacks:

1. Pirate actions where people are taken hostage for ransom. This type of piracy has become widespread since 2009. Thus, in December 2009, Somali pirates holding the Chinese bulk carrier De Xin Hai received \$ 4 million as ransom for a vessel. The money was delivered and lowered onto the deck of the captured vessel by helicopter. The pirates subsequently left the ship and fled in an unknown direction. The ship was later found 700 miles east of the Horn of Africa.

In the same year pirates released the Greek ship «Ariana» with 24 Ukrainian citizens on board. The ship owner paid a ransom of $\$ 2.8$ million for the release of the vessel. Pirates had captured the ship on May 2, 2009 to the north of Madagascar during its voyage from Brazil to the Middle East. In December 2010 pirates released the German tanker Marida Marguerite, captured in May of the same year in the Gulf of Aden for a ransom of $\$ 5.5$ million.

2. Pirates' seizure of oil and fuel tankers in order to sell the cargo. In these cases the pirates capture vessels specifically to pump out the oil and fuel for further resale.

For example, in April 2014 pirates attacked the tanker Naniwa Maru-1 off the west coast of Malaysia and pumped up to three million liters of diesel fuel into two other ships brought to the site of the attack.

In May of the same year pirates captured the tanker MT Orapin-4 en route to Indonesia. Pirates stole the diesel fuel from the ship and then released the ship with the crew (RIA-Novosti, 2014).

It can be seen that pirates from Asia and Africa are pursuing different goals in their criminal activities. African pirates specialize in hostage taking for ransom and Asian pirates resell stolen goods, oil and fuel.

V.L. Mikheev and A.Y. Pidzhakov identify certain characteristics of pirate attacks by the modes of action of the pirates: "Indonesian" and "Somali". The first type, common in the waters of Southeast Asia, involves the hunt for valuable cargo. The second type of attack, practised mostly in African waters, aims to take hostages for ransom (Mikheev \& Pidzhakov, 2010).

In our view, this classification is singularly unsuccessful since it considers only two types of pirate attack based on the region and the degree of their prevalence. However, the pirates have upgraded their activities and the geography of their attacks is changing. Therefore, pirate attacks can evolve into other forms; they can be one-off and not widespread occurrences. This study will now focus on the features of maritime terrorism and its basic forms.

\subsection{The differences between piracy and maritime terrorism}

During the beginning of the $90 \mathrm{~s}$, terrorism was a common expression used once in a while among scholars of international relations (Plaku \& Ibrahimi (Tafa), 2013).

The question of the relationship between maritime terrorism and piracy is often encountered by researchers who are engaged in maritime security. However, these scientific papers either do not distinguish between these crimes or the distinction is made on minor grounds.

Thus, S.O. Dopilka sees the difference between terrorism and piracy in the following: the former is done based on a political directive and the latter for personal reasons (Dopilka, 1993). However, we agree with this statement only partially. After all, terrorism is characterized not only by a specific purpose (political), it causes more substantial damage than acts of piracy and the number of victims in a terrorist attack can be much higher.

L.A. Modzhoryan believes that the notion of maritime terrorism should be included in the concept of piracy as there is no fundamental difference between them. Some of the common characteristics of maritime terrorism and piracy include the detriment to freedom of the seas, a threat to the safety of navigation, and the authors consider "bullying" to be their peculiar feature, i.e. criminal behavior, intended to cause fear paralyzing attack victims. (Modzhoryan, 1991). IMO experts also believe that piracy should be qualified as international terrorism as piracy has acquired particularly dangerous forms in recent years.

In our opinion, regarding piracy and terrorism in terms of their similarities and differences, one can only partly agree with those views. In spite of the similar nature of the methods and means of committing these crimes, the terrorists in their acts pursue a different goal than pirates. Like any other form of terrorism, maritime terrorism aims at intimidating and frightening society and authorities to influence the decisions of the authorities or international organizations, decisions that are most often of a political nature. Thus, the purpose of maritime terrorism is to achieve mainly political benefits. Piracy pursues a different purpose - the acquisition of another's property, i.e. piratical motivation is of a purely selfish character. 
Violent acts of terrorism aim to have an impact on third parties for the purpose of forcing them into behavior that is advantageous to criminals. For pirates the bullying of victims is a pivotal moment in the process of an illegal act; as for the terrorists, it serves as a means to intimidate third parties who have an interest in the safety of victims of the attack.

While the pirate criminal activity terminates with the seizure of the ship, people and their property, the terrorists' criminal activity only begins from that moment; the attainment of their goals is not connected with the behavior of the victims of the attacks in the course of violent action but with the behavior of the third parties on whom the violent action is designed to have an impact.

I.V. Shevchenko observes correctly that the distinguishing feature of terrorism is the deliberate creation of a climate of fear, depression and tension. Terrorism intentionally creates a climate of fear, not at the individual or narrow group level, but at the social level and appears to be an objectively formed socio-psychological factor that affects other people and forces them to undertake any demanded action in the interests of the terrorists or to accede to their terms. In this case fear serves as a lever with a purposeful impact in which the creation of a climate of fear appears to not be a goal in itself but rather as a means of achieving a goal (Shevchenko, 2011).

Obviously both maritime terrorism and piracy are serious threats to the safety of navigation, the universally recognized principles of freedom of the seas and often pose a threat to the world.

Maritime terrorism has evolved from piracy. In modern conditions under maritime terrorism we understand the seizure of ships for the purpose of a forcible change of their course, the taking of hostages from among the passengers and crews of ships, ferries, boats and other vessels designed for people's transportation, and seajacking (Stepanov, 2000).

When describing maritime terrorism it is necessary to mention the "Liberation Tigers of Tamil Eelam" a group notorious for its activities. Representatives of that organization are fighting for an independent Tamil state in the northeast of Sri Lanka. Their criminal activity is an example of terrorism, the purpose of which is political in nature. They have made the greatest number of attacks at sea. Recognized among Asian terrorist organizations, the group has created the most advanced naval component - virtually the world's largest non-governmental fleet, effectively operating in two separate units. The first of them, the "Sea Tigers", is the amphibious group, numbering 3-4 thousand well-trained and equipped maritime terrorists who have the opportunity to carry out acts of terrorism and piracy both in territorial and coastal waters and on the high seas.

\subsection{The categories of threats of terrorist attacks on maritime transport}

Analysis of the current dynamics and tendencies in international terrorism in general allows us to distinguish the following risk categories in relation to maritime transport:

- seajacking, seizure of ships or control of them by force or threat of use of force or by any other means of intimidation;

- an act of violence against any person on board a ship (the port area) if that act is likely to endanger the safe navigation of the vessel (port security);

- the destruction of a ship or inflicting damage to the ship or its cargo that might endanger the safe navigation of the ship or port security;

- placing or taking actions to place on board a vessel (including within the port) any devices that could destroy that ship or cause damage to that ship or its cargo which threatens to or does endanger the safe navigation of the vessel or port security;

- the use of vessels by members of international terrorist groups as an indirect (oblique) object of the terrorist activity;

- the use of sea transport by persons involved in transnational organized crime as a means of realizing their illegal activity;

- the destruction of marine navigation equipment or causing serious damage or interfering with its operation, if any such act is likely to endanger the safe navigation of vessels;

- the destruction of port facilities or causing serious damage that threatens or may threaten the safety of navigation and port security;

- deliberately giving false information that could jeopardize the safety of navigation and port (http://news.neobroker.ru/ru/news5809.html, 2015).

The common factor in acts of maritime terrorism and piracy is that they are characterized by significant public danger and as a result of their commission there can be grave consequences (destruction of vessels and people's 
deaths, significant pollution of the marine environment, etc.), as well as complications in interstate relations.

Y.S. Romashev observes correctly that, "these crimes have a significant physical and psychological impact on the world community in the truest sense of the word as they "terrorize" the populations of coastal states and those involved in international shipping, have a negative impact on the strengthening of international relations and affect the vital interests of states in various spheres" (Romashev, 2001).

However, the international community identifies piracy as a separate type of crime, formulating a separate structure for that. This is done, first of all, with regard to objectives and motives of committing pirate acts that are clearly nonpolitical in nature.

\section{Conclusions}

In conclusion, it should be noted that piracy and maritime terrorism pose a serious threat to the safety of navigation, people's lives and well-being, as well as complicating interstate relations.

At the present time we can distinguish different kinds of acts of piracy and maritime terrorism. In many ways these types can be defined depending on the nature of the attacks, methods and tools, as well as locations and regions of pirates' and maritime terrorists' activity.

Today, piracy and terrorism are similar in the nature of their actions. They aim to attack and (or) destroy vessels, steal cargo and other valuables and take hostages, etc.

However, despite some commonality in the nature and mode of action of pirates, terrorists are pursuing different goals which are not self-oriented. For terrorists any act of violence has a special meaning. Terrorists do not commit crimes without intending to publicize their activities and exert psychological pressure on the public or government structures. For pirates, contrarily, the seizure of a ship and the people and property on board is carried out for profit, i.e. for selfish reasons.

Thus, considering the above-mentioned crimes, we can talk about some similarities of piracy to the terrorist acts that threaten the safety of maritime navigation. However, these crimes cannot be regarded as being the same, especially in view of the fact that such acts belong to different social phenomena and penal acts.

\section{Acknowledgement}

The scientific results were obtained in the framework of the state order of the Ministry of Education and Science of the Russian Federation, task № 29.763.2014 / K.

\section{References}

Dopilka, S.O. (1993). Criminal Liability for Terrorism and Piracy at Sea (Abstract Dissertation Candidate of Law). Kiev.

Eshchenko, Y. \& Novikov, A. (2014). Methods of Counteracting Maritime Piracy. Sea collection, 1, 55-58.

Geneva Convention on the High Seas of 29 April, 1958. Access: Consultant Plus.

Instances of Pirate Attacks on Merchant Ships and Cargo Vessels in 2009-2014. http://ria.ru/spravka/20140724/1017319175.html

Knyazeva, N.A. \& Knyazeva, E.A. (2014). The Application of International Law Standards as a Means to Counteract Maritime Terrorism and Piracy. Criminological magazine, 4, 175-187.

Korobeev, A.I. (2015). Transport Crime and Offences. Moscow.

Kurshev, M. (2006). Piracy and Terrorism at Sea. Criminal Law, 3. 124.

Kurshev, M. (2006). Maritime Piracy - a Kind of International Terrorism. Criminal Law, 4. 133.

Maritime Terrorism is Spinning up. April 24, 2013 http://news.neobroker.ru/ru/news5809.html

Mikheev, V.L. \& Pidzhakov, A.Y. (2010). The International Legal Basics for Counteracting Piracy. Scientific Notes of the St. Petersburg's Branch of the Russian Customs Academy Named after V.B. Bobkov, 2 (36), 205-216.

Modzhoryan, L.A. (1991). Terrorism at Sea. The Struggle of the State to Ensure the Safety of Maritime Navigation. Moscow.

Pidzhakov, A.Y., Mayor, M.N., Balyasnikov, V.V., Bayramov, S.B. \& Zeleneva, I.V. (2015). Safety and Terrorism: Problems of Correlation, Asian Social Science, 7 (11), 159-168.

Plaku, E. \& Ibrahimi (Tafa), E. (2013). NATO's Current Policies on War Against Terrorism. Mediterranean Journal of Social Sciences, Vol. 4, No 10. http://www.mcser.org/journal/index.php/miss/article/view/1201/1230

Protocol for the Suppression of Illegal Acts Directed against the Safety of Fixed Platforms Located on the Continental Shelf (SUAPROT) of March 10, 1988. Access: Consultant Plus.

Report of the International Maritime Bureau (2015). http://www.msecurity.ru/rus/page161/

Romashev, Y.S. (2001). The Fight against International Crimes Committed at Sea (Terrorism, Piracy, Drug Trafficking). Moscow.

Stepanov, E.I. (2000). Modern Terrorism: Its Current State and Prospects. Moscow. 
Shevchenko, I.V. (2011). Criminal Liability for Terrorist Activities. Moscow.

The Rome Convention on the Suppression of Unlawful Acts against the Safety of Maritime Navigation of 10 March, 1988. Access: Consultant Plus.

UN Conventions on the Law of the Sea at 10 December, 1982. Access: Consultant Plus. 